\title{
MICROWAVE-ASSISTED SYNTHESIS OF BIOLOGICALLY ACTIVE AMIDE DERIVATIVES OF NAPHTHENIC ACIDS UNDER NEAT CONDITIONS
}

\author{
Ljubica Grbović ${ }^{1}$, Bojana Vasiljevićc ${ }^{1, *}$, Ksenija Pavlović1, Timea Hajnal-Jafari ${ }^{2}$, \\ Simonida Đurić ${ }^{2}$, Mirjana Popsavin ${ }^{1}$, Slavko Kevrešan ${ }^{2}$ \\ ${ }^{1}$ Department of Chemistry, Biochemistry and Environmental Protection, Faculty of Sciences, \\ University of Novi Sad, Trg DositejaObradovića 3, 21000 Novi Sad, Serbia \\ ${ }^{2}$ Department of Field and Vegetable Crops, Faculty of Agriculture, University of Novi Sad, \\ Trg DositejaObradovića 8, 21000 Novi Sad, Serbia \\ bojana.vasiljevic@dh.uns.ac.rs, vasiljevicbojana9@gmail.com
}

\begin{abstract}
Within the field of green chemistry, a noticeable results were obtained in the solvent-free synthesis of amide derivatives of naphthenic acids under microwave irradiation. Naphthenic acid amides, anilides, and morpholides were synthesized directly from free carboxylic acids and amines in the absence of solvent and catalyst under high-temperature heating in a closed-vessel system of microwave reactor. With this new and efficient method, different primary, secondary, and tertiary amide derivatives of naphthenic acids were obtained in good to excellent yields. Synthesized derivatives were assayed as plant rooting agents for their stimulative effects on the formation of adventitious roots in sunflower cuttings and susceptibility for growth stimulation of Pseudomonas sp. strains.
\end{abstract}

Keywords: green chemistry; naphthenic acid amides; solvent-free synthesis; plant rooting agents; bacterial proliferation

\section{МИКРОБРАНОВО ПОМОГНАТА СИНТЕЗА НА БИОЛОШКИ АКТИВНИ АМИДНИ ДЕРИВАТИ НА НАФТЕНСКИ КИСЕЛИНИ ВО ЦВРСТА ФАЗА}

Во рамките на зелена хемија се добиени значајни резултати при синтеза на амидни деривати на нафтенски киселини во отсуство на растворувач со микробранова ирадијација. Синтетизирани се амиди, анилиди и морфолиди на нафтенска киселина директно од слободни карбоксилни киселини и амини во отсуство на растворувач и катализатор со загревање на висока температура во затворен сад на микробранов реакторски систем. Со овој нов и ефикасен метод се добиени разни примарни, секундарни и терцијарни амидни деривати на нафтенски киселини со добар до одличен принос. Синтетизираните деривати беа испитани како стимулативни средства за поттикнување раст на странични корења кај гранчиња од сончоглед и за подложност на стимулирање раст на видовите на Pseudomonas sp.

Клучни зборови: зелена хемија; амиди на нафтенска киселина; синтеза во отсуство на растворувач; средства за поттикнување корења; бактериско размножување

\section{INTRODUCTION}

The amide group is an important functional group because of its presence in a large number of biomolecules, synthetic intermediates, and active pharmaceutical products or prodrugs [1-5]. In ad- dition to amide bonds, incorporation of cyclic amines, like morpholine, promote antimicrobial activity of some pharmaceutical ingredients $[6,7]$. The most common methods for amide synthesis involve either conversion of carboxylic acids to more reactive functional groups [8-10] or in situ 
activation using coupling reagents [11-14]. Although good results were obtained with both approaches, the main drawbacks are long reaction time, low yield and low atom economy. Also, use of organic solvents and expensive or toxic reagents may lead to the formation of by-products, requiring further separations steps. Furthermore, in previous studies the main substrates were structurally simple monocyclic or short alkyl chain individual carboxylic acids.

In recent years, microwave irradiation as a non-conventional energy source has become a very popular and useful technology in organic chemistry [15-17]. Microwave-assisted synthesis of amides shows considerable improvement in overall synthetic methods considering the presence of different catalysts and coupling reagents [18-21]. This technology has also been utilized in reactions of carboxylic acid esters and amines in the solid phase, using basic alumina as a solid support [22], as well as in reactions of amines with other acyldonors [23]. Pyrolysis of ammonium salt, which requires high-temperature heating [24], was successfully achieved under microwave irradiation $[25,26]$.

Petroleum acids represent a complex mixture of carboxylic acids (aliphatic, alicyclic, aromatic acids, etc.) that are found in crude oils, where their contents and composition depend on the source of oil. The term naphthenic acids (NAs), as commonly used in the petroleum industry, refers to a collection of alkyl-substituted aliphatic and cyclic monocarboxylic acids with an empirical formula of $\mathrm{C}_{n} \mathrm{H}_{2 n-z} \mathrm{O}_{2}$, where $n$ is the number of carbon atoms and $z$ is the hydrogen deficiency due to ring formation. Namely, NAs are naturally occurring compounds that constitute part of the petroleum acids. Furthermore, although many authors have assumed NAs are comprised only of alicyclic acids, it is likely that aromatic acids [27] are also present. These complex mixtures of carboxylic acids have attracted the attention of scientists in recent years $[28,29]$. In addition to their widespread commercial uses [30], they are also prevalent in refinery process wastewater, which is the source of NAs contamination in the environment. It has been reported [31-34] that natural mixtures of NAs exhibit physiological activity similar to plant hormones of the auxin and gibberelin type. These carboxylic acids stimulate the rooting of cuttings and the lateral branches of sunflower [35], as well as poplar hardwood cuttings [36]. The biodegradation potential of microorganisms and their utilization of some environmental pollutants as sources of carbon and energy is well-known from the literature [37, 38]. Several studies have shown that NAs are susceptible to biodegradation, which decreases their concentration and reduces toxicity $[39,40]$.

The above significance of NAs prompted us to investigate a new application of environmentally toxic NAs by synthesizing new potentially biologically active compounds from natural materials. So far, amidation of a complex mixture of naturally occurring, structurally diverse carboxylic acids, as it is NAs, has been performed only conventionally via acid chlorides. In this context, we report the development of a versatile, mild, and efficient method for the synthesis of potentially biologically active amide derivatives of NAs directly from nonactivated carboxylic acids and amines in the absence of coupling reagents and solvents under microwave irradiation.

\section{EXPERIMENTAL}

Complex mixtures of natural NAs were isolated from an atmospheric oil fraction (distillation interval $168-290{ }^{\circ} \mathrm{C}$ ) of Vojvodina crude oil source "Velebit" by the method of alkaline extraction described in previous work [31,33]. Identification of NAs was performed by electrospray ionization mass spectrometry analysis. The average molecular mass of isolated NAs was determined (ASTM D3238) to be $262 \mathrm{~g} / \mathrm{mol}$, and this value was used in further experiments [31,33].

All reagents and solvents were obtained from commercial suppliers and used without further purification. Microwave-assisted reactions were carried out in a CEM Discover BenchMate single-mode microwave reactor $(300 \mathrm{~W}$ max magnetron power output) in $10 \mathrm{ml}$ sealed process Pyrex vials with magnetic stirring. The microwaveassisted reaction time was the hold time at the designed temperature. The reaction temperature was monitored by an external IR sensor. Reaction cooling was performed using compressed air after the heating period elapsed. Reactions were monitored by thin layer chromatography (TLC) on silica gel plates (Silica gel $60 \mathrm{~F}_{254}$ ). Purification of products was carried out by flash column chromatography using Kieselgel 60 (0.040-0.063, Merck). IR spectra were recorded with Nexus 670 spectrophotometer (Thermo-Nicolet) and the band positions $\left(\lambda_{\max }\right)$ are given in $\mathrm{cm}^{-1}$. NMR spectra were recorded on a Bruker AC $250 \mathrm{E}$ instrument, and chemical shifts are expressed in ppm downfield from TMS using $\mathrm{CDCl}_{3}$ as the solvent. The letters $\mathrm{s}, \mathrm{d}, \mathrm{t}, \mathrm{q}$, and $\mathrm{m}$ are used to indicate singlet, doublet, triplet, quad- 
ruplet, and multiplet. All organic extracts were dried with anhydrous $\mathrm{Na}_{2} \mathrm{SO}_{4}$. Organic solutions were concentrated in a rotary evaporator under reduced pressure at a bath temperature above $30^{\circ} \mathrm{C}$.

\subsection{Synthesis of $N$-phenylbenzamide 1}

Benzoic acid $(1.22 \mathrm{~g}, 10.0 \mathrm{mmol})$ and aniline $(0.912 \mathrm{ml}, 10.0 \mathrm{mmol})$ were placed into a 10 $\mathrm{ml}$ microwave process vial equipped with a magnetic stir bar. The reaction mixture was heated in a microwave reactor for $15 \mathrm{~min}$ at $270{ }^{\circ} \mathrm{C}$. After the reaction time had elapsed, the mixture was cooled to $45^{\circ} \mathrm{C}$ by gas jet cooling, dissolved in $\mathrm{CH}_{2} \mathrm{Cl}_{2}$, and washed with $1 \mathrm{M} \mathrm{HCl}, 5 \% \mathrm{NaHCO}_{3}$, and $\mathrm{H}_{2} \mathrm{O}$. After removing the solvent under vacuo, the residue was purified by flash column chromatography on silica gel (petroleum ether : ethyl acetate $=7: 3$ ) to obtain pure product 1 in the form of white crystals.

The same experimental procedure was used for the oil bath synthesis of compound 1. Instead of the microwave reactor, a preheated $\left(200{ }^{\circ} \mathrm{C}\right)$ silicone oil bath with magnetic stirring was used. After $24 \mathrm{~h}$ of refluxing, further isolation and purification of the final product, white crystals of compound 1 were obtained.

\subsection{Microwave-assisted synthesis of NA anilides 2 and NA morpholides 3}

The mixture of NAs $(5 \mathrm{mmol})$ and amine (5 mmol) was placed in a $10 \mathrm{ml}$ reaction vial equipped with magnetic stir bar. The reaction mixture was heated with stirring at $270{ }^{\circ} \mathrm{C}$ for 15 min of microwave irradiation for the synthesis of compound 2 and was heated for $10 \mathrm{~min}$ for the synthesis of compound 3. Upon cooling to $45^{\circ} \mathrm{C}$, the reaction mixture was dissolved in $\mathrm{CH}_{2} \mathrm{Cl}_{2}$ and washed with $1 \mathrm{M} \mathrm{HCl}, 5 \% \mathrm{NaHCO}_{3}$, and $\mathrm{H}_{2} \mathrm{O}$. After removing the solvent under vacuo, the residue was purified by flash column chromatography on silica gel (dichloromethane $:$ ethyl acetate $=9.5$ $: 0.5)$ to obtain products $\mathbf{2}$ and $\mathbf{3}$ as a yellow oil.

\subsection{Microwave-assisted synthesis of NA amides 4}

A mixture of NAs $(0.28 \mathrm{~g}, 1 \mathrm{mmol})$ and urea $(0.12 \mathrm{~g}, 2 \mathrm{mmol})$ was placed in a $10 \mathrm{ml}$ reaction vessel equipped with magnetic stir bar. The mixture was heated with stirring at $180{ }^{\circ} \mathrm{C}$ for 1 min of microwave irradiation. Upon cooling to room temperature, the reaction mixture was dissolved in EtOAc and washed with $2 \mathrm{M} \mathrm{HCl}, 5$ $\% \mathrm{NaHCO}_{3}$ and $\mathrm{H}_{2} \mathrm{O}$. After removing the solvent under vacuo, the residue was purified by flash col- umn chromatography on silica gel (ethyl acetate : petroleum ether $=7: 3$ ) to obtain product 4 as a yellow oil. The same experimental procedure was used for the synthesis of compound $\mathbf{4}$ in the presence of imidazole $(0.068 \mathrm{~g}, 1 \mathrm{mmol})$ or zirconyl chloride $(0.0178 \mathrm{~g}, 0.1 \mathrm{mmol})$, obtaining product $\mathbf{4}$ as a yellow oil.

\subsection{Rooting of sunflower cuttings}

The plant rooting biological tests of young sunflower cuttings were performed according to the procedure previously described [35].

\subsection{Growth stimulation of five bacterial isolates of Pseudomonas sp.}

Bacterial isolates of Pseudomonas sp. (marked with P1, P2, P3, P4, and P5) were grown in liquid King B medium [41] at $28{ }^{\circ} \mathrm{C}$ for $24 \mathrm{~h}$ in the Microbiology Laboratory, Faculty of Agriculture, University of Novi Sad. The incubation of bacterial isolates was performed on a rotary shaker $(120 \mathrm{rpm})$, and a final concentration of $10^{8} \mathrm{CFU}$ $\mathrm{m} / \mathrm{l}$ was obtained after $24 \mathrm{~h}$. The selected bacterial isolates were subjected to $450 \mu \mathrm{l}$ of NAs or NA amides, followed by incubation. Control treatments contained only the bacterial strains. The growth of bacterial isolates was determined on a spectrophotometer at $\mathrm{OD}_{600}$ after $24 \mathrm{~h}$ and $48 \mathrm{~h}$ [42]. The assay was carried out three times.

$N$-phenylbenzamide (1): Yield: 74\%; IR $\left(\mathrm{KBr}, \mathrm{cm}^{-1}\right): v=1653(\mathrm{C}=\mathrm{O}$ stretching of amide group); ${ }^{1} \mathrm{H}$ NMR $\left(250 \mathrm{MHz}, \mathrm{CDCl}_{3}\right): \delta=7.10$ $7.98\left(\mathrm{~m}, 10 \mathrm{H}\right.$, Ar-H) $10.28(\mathrm{~s}, 1 \mathrm{H}, \mathrm{N}-\mathrm{H}) ;{ }^{13} \mathrm{C}$ NMR $\left(62.9 \mathrm{MHz}, \mathrm{CDCl}_{3}\right): \delta=120.64,123.91$, $127.78,128.54,128.76,131.71,135.09,139.24$ $(\mathrm{Ar}-\mathrm{C}), 165.86(\mathrm{C}=\mathrm{O})$.

NA anilides (2): Yield: $76 \%$; IR $\left(\mathrm{KBr}, \mathrm{cm}^{-1}\right)$ : $v=1660(\mathrm{C}=\mathrm{O}$ stretching of amide group $) ;{ }^{1} \mathrm{H}$ NMR $\left(250 \mathrm{MHz}, \mathrm{CDCl}_{3}\right): \delta=0.28-2.10(\mathrm{~m}$, $\left.\mathrm{CH}+\mathrm{CH}_{2}+\mathrm{CH}_{3}\right), 6.62-7.28(\mathrm{~m}, 5 \mathrm{H}, \mathrm{Ar}-\mathrm{H}), 7.58-$ $8.20(\mathrm{~s}, 1 \mathrm{H}, \mathrm{NH}) ;{ }^{13} \mathrm{C} \mathrm{NMR}\left(62.9 \mathrm{MHz}, \mathrm{CDCl}_{3}\right): \delta=$ 14.07-47.50 $\left(\mathrm{C}+\mathrm{CH}+\mathrm{CH}_{2}+\mathrm{CH}_{3}\right), 119.98,123.92$, 128.69, 138.12 (Ar-C), 171.73-175.20 (C=O).

NA morpholides (3): Yield: 97\%; IR (KBr, $\left.\mathrm{cm}^{-1}\right): v=1651(\mathrm{C}=\mathrm{O}$ stretching of amide group $)$; ${ }^{1} \mathrm{H}$ NMR $\left(250 \mathrm{MHz}, \mathrm{CDCl}_{3}\right): \delta=0.60-2.41(\mathrm{~m}$, $\left.\mathrm{CH}+\mathrm{CH}_{2}+\mathrm{CH}_{3}\right), \quad 3.35-3.68(\mathrm{~m}, 8 \mathrm{H}$, morpholine ring); ${ }^{13} \mathrm{C}$ NMR $\left(62.9 \mathrm{MHz}, \mathrm{CDCl}_{3}\right): \delta=14.07-$ $39.24 \quad\left(\mathrm{C}+\mathrm{CH}+\mathrm{CH}_{2}+\mathrm{CH}_{3}\right), \quad 45.97, \quad 46.19$ $\left(\mathrm{CH}_{2} \mathrm{NCH}_{2}\right)$, 66.57, $66.85\left(\mathrm{CH}_{2} \mathrm{OCH}_{2}\right), 171.58-$ $172.85(\mathrm{C}=\mathrm{O})$.

NA primary amides (4): Yield: 50\%; IR $\left(\mathrm{KBr}, \mathrm{cm}^{-1}\right): v=1658(\mathrm{C}=\mathrm{O}$ stretching of amide 
group); ${ }^{1} \mathrm{H}$ NMR $\left(250 \mathrm{MHz}, \mathrm{CDCl}_{3}\right): \delta=0.40-2.56$ $\left(\mathrm{m}, \mathrm{CH}+\mathrm{CH}_{2}+\mathrm{CH}_{3}\right), 5.85-6.33(\mathrm{~s}, 2 \mathrm{H}) ;{ }^{13} \mathrm{C} \mathrm{NMR}$ $\left(62.9 \mathrm{MHz}, \mathrm{CDCl}_{3}\right): \delta=14.02,14.31,19.05-50.27$ $\left(\mathrm{CH}+\mathrm{CH}_{2}+\mathrm{CH}_{3}\right), 175.94-176.13(\mathrm{C}=\mathrm{O})$.

\section{RESULTS AND DISCUSSION}

Benzoic acid was chosen as a "model" petroleum acid for reaction optimization because of the structural complexity of petroleum acids and the low reactivity of aromatic carboxylic acids in amidation reactions. Using an equimolar ratio, the reaction of benzoic acid and aniline under catalystfree and solvent-free conditions was considered as a standard model reaction. Table 1 shows that the synthesis of $\mathrm{N}$-phenylbenzamide $\mathbf{1}$ in temperaturecontrol mode of the microwave reactor was significantly shorter and had higher yields compared to the results obtained under conventional heating.

\section{Table 1}

\section{Synthesis of N-phenylbenzamide 1 by conventional heating $(\Delta)$ or under microwave irradiation $(M W)^{a}$}

\begin{tabular}{cccc}
\hline \hline Entry & Heating & Reaction time (min) & Yield $(\%)^{\mathrm{b}}$ \\
\hline 1 & $\Delta$ & 1440 & 61 \\
2 & $\mathrm{MW}$ & 15 & 74 \\
\hline \hline
\end{tabular}

The observed enhancement in the microwave-heated reaction is a consequence of the high reaction temperature that can be rapidly attained when irradiating carboxylic acid and amine under closed-vessel conditions in a microwave field. It should be noted that the increase in reaction time did not improve the yield of the final product.

Using the established conditions, the scope of this method was tested with natural NAs, which were previously isolated and determined [31, 33], and the results are summarized in Table 2. It was observed that the NAs reacted efficiently with different amines under high-temperature heating in the closed-vessel system of the microwave reactor. The maximal operative temperature for these reaction systems was $270{ }^{\circ} \mathrm{C}$. Microwave-assisted synthesis of NA anilides 2 was completed in 15 minutes of microwave irradiation, leading to $76 \%$ isolated yield (Table 2, entry 1 ), while synthesis of NA morpholides 3 lasted 10 minutes, providing $97 \%$ isolated yield of product (Table 2, entry 2).
The alternation of carboxylic functional goups of NAs with nonpolar hydrocarbon part [36, 38] to amides was tracked by IR and NMR spectral data.

Table 2

Microwave-assisted synthesis of NA anilides 2 and NA morpholides $\mathbf{3}^{a}$

\begin{tabular}{ccccc}
\hline \hline Entry & Amine & Product & $\begin{array}{c}\text { Reaction time } \\
(\mathrm{min})\end{array}$ & $\begin{array}{c}\text { Yield } \\
(\%)^{\mathrm{b}}\end{array}$ \\
\hline 1 & $\mathrm{C}_{6} \mathrm{H}_{5} \mathrm{NH}_{2}$ & $\mathbf{2}$ & 15 & 76 \\
2 & $\mathrm{C}_{4} \mathrm{H}_{9} \mathrm{NO}$ & $\mathbf{3}$ & 10 & 97 \\
\hline \hline
\end{tabular}

Surprisingly, the results presented in Table 3 show that direct, solvent-free synthesis of NA primary amides $\mathbf{4}$ occurred at a much lower rate than synthesis of secondary and tertiary NA amides (Table 2, entries 1 and 2). Furthermore, it was observed that the reaction of NAs and urea was performed under a lower reaction temperature. In the closed-vessel system of the microwave reactor, liberation of ammonia increased the internal pressure, with a maximum operative reaction temperature of $180^{\circ} \mathrm{C}$, thus decreasing the product yield.

Previous results were the motivation for finding potent, non-toxic, and highly reactive catalysts for the synthesis of NA primary amides in higher yield under solvent-free conditions. The catalytic ability of zirconyl chloride and imidazole for the synthesis of primary amides by direct reaction of carboxylic acid and urea under microwave irradiation is well known from the literature [21, 43]. In the reaction of natural NAs and urea, these catalysts demonstrated their efficiency (Table 3, entries 2 and 3).

T a ble 3

Microwave-assisted synthesis of NA primary amides $\mathbf{4}^{a}$

\begin{tabular}{cccc}
\hline \hline Entry & Catalyst & Reaction time (min) & Yield $(\%)^{\mathrm{b}}$ \\
\hline 1 & - & 1 & 12 \\
2 & imidazole & 1 & 50 \\
3 & $\mathrm{ZrOCl}_{2}$ & 1 & 36 \\
\hline \hline
\end{tabular}

${ }^{\mathrm{a}}$ Reaction conditions: naphthenic acids $(1.0 \mathrm{mmol})$, urea $(2.0$ $\mathrm{mmol}), 270{ }^{\circ} \mathrm{C}$.

${ }^{\mathrm{b}}$ Isolated yield of $\mathbf{6}$. 
Among them, imidazole showed higher catalytic efficiency compared to zirconyl chloride in the synthesis of NA primary amides in the closed vessel system of the microwave reactor (Table 3, entries 2 and 3).

The study of the biological activity of synthesized NA derivatives as plant rooting agents showed the stimulative effect of amide derivatives of NAs on the formation of adventitious roots in sunflower cuttings (Fig. 1). A significant stimulative effect of NA morpholides and NA anilides was noticed at $10^{-6} \mathrm{~mol} / \mathrm{l}$ and $10^{-7} \mathrm{~mol} / \mathrm{l}$. The number of adventitious roots per plant was almost twice as high for plants treated with compounds $\mathbf{2}$ and $\mathbf{3}$ in contrast to the results after treatment with NAs.

In Table 4, the results of the microbiology experiments are presented. The results show the growth stimulation of the examined strains as incubation time increased. The highest bacterial growth of $\mathrm{P} 2$ and $\mathrm{P} 4$ strains were observed after 48 $\mathrm{h}$ of incubation for NAs, NA primary $\mathbf{4}$, and secondary amides $\mathbf{2}$. These results indicate a possible simulative effect of NAs and their derivatives on strain proliferation in both examined concentrations, compared to the control. NAs and NA primary amides promote the number of strains P5 at lowest concentration $\left(10^{-7} \mathrm{~mol} / \mathrm{l}\right)$. Strain $\mathrm{P} 1$ was promoted after treatment with NA primary amides, whereas strain P3 showed the lowest bacterial growth in all cases.

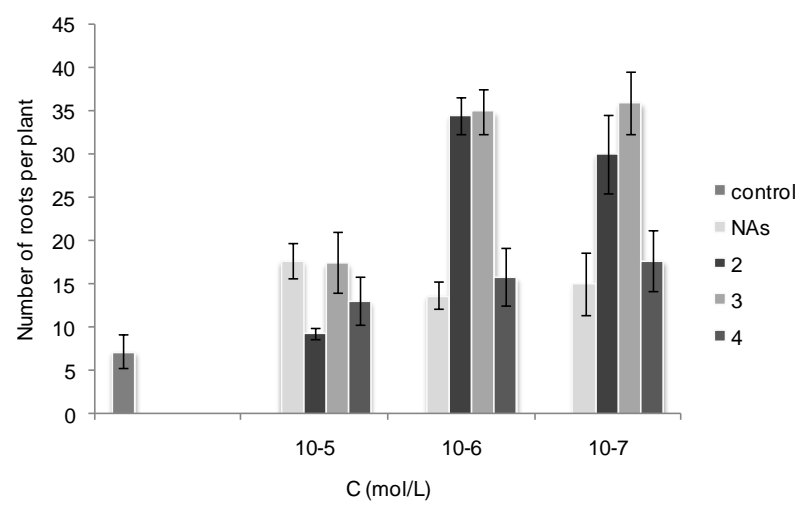

Fig. 1. Effect of NAs and NA amides 2, 3, and $\mathbf{4}$ on formation of adventitious roots in sunflower cuttings under different concentrations

\section{Table 4}

The influence of NAs, NA primary amides 4, and NA anilides 2 on the number of Pseudomonas sp. strains $\left(\times 10^{8} \mathrm{CFU} \mathrm{m} / \mathrm{l}\right)$

\begin{tabular}{|c|c|c|c|c|c|c|c|c|}
\hline \multirow{4}{*}{ Strains } & \multirow{4}{*}{ Time of incubation (h) } & \multirow{4}{*}{ Control } & \multicolumn{6}{|c|}{ Compound } \\
\hline & & & \multicolumn{2}{|c|}{ NAs } & \multicolumn{2}{|c|}{2} & \multicolumn{2}{|c|}{4} \\
\hline & & & \multicolumn{6}{|c|}{ Concentration } \\
\hline & & & $10^{-5}$ & $10^{-7}$ & $10^{-5}$ & $10^{-7}$ & $10^{-5}$ & $10^{-7}$ \\
\hline \multirow{2}{*}{$\mathrm{P} 1$} & 24 & 1.80 & 1.50 & 0.28 & 0.69 & 1.08 & 2.02 & 0.69 \\
\hline & 48 & 2.24 & 1.38 & 1.47 & 1.74 & 1.92 & 2.80 & 2.42 \\
\hline \multirow{2}{*}{$\mathrm{P} 2$} & 24 & 2.58 & 2.05 & 2.16 & 2.70 & 2.56 & 2.69 & 2.26 \\
\hline & 48 & 1.86 & 2.96 & 2.72 & 3.20 & 2.80 & 3.20 & 3.12 \\
\hline \multirow{2}{*}{$\mathrm{P} 3$} & 24 & 2.48 & 1.50 & 1.60 & 1.63 & 1.50 & 1.80 & 1.26 \\
\hline & 48 & 3.04 & 2.96 & 2.88 & 2.18 & 3.04 & 3.06 & 2.88 \\
\hline \multirow{2}{*}{$\mathrm{P} 4$} & 24 & 2.53 & 1.81 & 1.87 & 1.28 & 1.68 & 1.55 & 1.50 \\
\hline & 48 & 2.56 & 3.04 & 2.80 & 3.20 & 3.20 & 2.72 & 2.86 \\
\hline \multirow{2}{*}{ P5 } & 24 & 2.22 & 1.98 & 1.86 & 2.02 & 1.57 & 1.89 & 2.00 \\
\hline & 48 & 2.58 & 2.40 & 2.96 & 2.56 & 2.26 & 2.24 & 2.90 \\
\hline
\end{tabular}

As can be seen from the data presented in Table 5, NA tertiary amides $\mathbf{3}$ showed growth stimulation only for strains P4 and P5.

After $48 \mathrm{~h}$ of incubation, better effects of NAs and their synthesized amide derivatives could be related to the fact that increasing trend in bacterial number is time consuming, as a consequence of bacterial adaptation mechanism and induction of some mechanism that help her to survive and growth in new condition [38]. Furthermore, it has been previously shown that an increase in the concentration of NAs results in a decrease in the degradative ability of Pseudomonas putida [44]. However, in the present study, the growth stimula- 
tion of bacterial strains was mostly observed after treatmant with higher concentrations of NAs, as well as higher concentrations of NA primary $\mathbf{4}$, secondary $\mathbf{2}$ (Table 4 ), and tertiary amide $\mathbf{3}$ (Table $5)$.

\section{Table 5}

\section{The influence of NA morpholides 3 on the number of Pseudomonas sp. strains $\left(\times 10^{8} \mathrm{CFU} \mathrm{m} / \mathrm{l}\right)$}

\begin{tabular}{cccccc}
\hline \hline & \multirow{2}{*}{$\begin{array}{c}\text { Time of } \\
\text { incubation }\end{array}$} & & \multicolumn{3}{c}{ Compound 3 } \\
\cline { 3 - 6 } Strains & $(\mathrm{h})$ & Control & $10^{-3}$ & $10^{-5}$ & $10^{-7}$ \\
\hline \multirow{2}{*}{ P4 } & 24 & 0.79 & 0.94 & 1.00 & 0.86 \\
& 48 & 3.20 & 3.04 & 2.88 & 2.56 \\
& 24 & 1.79 & 1.44 & 1.33 & 1.10 \\
P5 & 48 & 1.82 & 2.16 & 2.08 & 1.89 \\
\hline \hline
\end{tabular}

NA primary amides and NA anilides showed a higher stimulative effect on strain P2 compared to the results obtained after treatment with NAs, while strain $\mathrm{P} 4$ was more stimulated in the presence of NA anilides. Additionally, with regard to the bacterial growth of strains P3 only after treatment with NA amides, it should be assumed that NA derivatives have higher stimulative effect on examined Pseudomonas sp. strains compare to the NAs. These observations are in good correlation with results obtained from Ebrahimi [38] and Clemente [45]. While researching the bioremediation of oil-pollutants, the conclusion was that the structure of hydrocarbon compounds, bacterial species and incubation time were the main factors determining the level of biodegradability.

\section{CONCLUSION}

In conclusion, a simple, quick, and versatile method for the preparation of amide derivatives of NAs under microwave irradiation was achieved. Starting from an equimolar mixture (atomeconomical synthesis) of amine and a complex mixture of natural NAs, high yields of NA anilides and NA morpholides (76\% and 97\%, respectively) were obtained at high temperatures in the closedvessel system of a microwave reactor. Efficient, uncatalyzed amidations of NAs were carried out under solvent-free conditions. Compared to the conventional protocol, a dramatic reduction in overall processing time from hours to a few minutes was achieved, indicating the influence of reaction temperature on the microwave-assisted formation of amide derivatives of NAs. Solventfree synthesis of NA primary amides required the presence of imidazole as a catalyst for higher yield. Biological activity studies of synthesized amide derivatives of NAs as plant rooting agents revealed that chemical transformation of carboxylic functional groups to an amide significantly enhanced the stimulative effect of the synthesized NA derivatives on the formation of adventitious roots in sunflower cuttings. Moreover, the growth stimulation of Pseudomonas sp. strains suggests the possible degradation potential of amide derivatives of NAs in contrast to NAs. Concerning the importance of bioremediation as one of the principal strategies for remediation, these results could be of great interest for further research into crude oil degradation.

Acknowledgment. This study was supported by the Ministry of Education, Science and Technological Development of the Republic of Serbia, Project No. 172006.

\section{REFERENCES}

[1] E. Valeur, M. Bradley, Amide bond formation: beyond the myth of coupling reagents, Chem. Soc. Reviews 38, 606-631 (2009). DOI: 10.1039/B701677H

[2] R. K. Mylavarapu, G. C. M. Kondaiah, N. Kolla, R. Veeramalla, P. Koilkonda, A. Bhattacharya, R. Bandichhor, Boric acid catalyzed amidation in the synthesis of active pharmaceutical ingredients, Org. Process Res. Dev. 11, 1065-1068 (2007). DOI: 10.1021/op700098w

[3] T. Nabe, Y. Kuriyama, N. Mizutani, S. Shibayama, A. Hiromoto, M. Fujii, K. Tanaka, S. Kohno, Inhibition of hematopoietic prostaglandin D synthase improves allergic nasal blockage in Guinea pigs, Prostaglandins Other Lipid Med. 95, 27-34 (2011).

DOI: $10.1016 / j$.prostaglandins.2011.05.001

[4] N. M. Tsutahara, Y. S. Weems, J. A. Arreguin-Arevalo, T. M. Nett, M. E. LaPorte, J. Uchida, J. Pang, T. McBride, R. D. Randel, C. W. Weems, Effects of endocannabinoid 1 and 2 (CB1; CB2) receptor agonist on luteal weight, circulating progesterone, luteal mRNA for luteinizing hormone (LH) receptors, and luteal unoccupied and occupied receptors for $\mathrm{LH}$ in vivo in ewes, Prostaglandins Other Lipid Med. 95, 17-24 (2011). DOI: $10.1016 /$ j.prostaglandins.2010.11.002

[5] N. Kushwaha, R. K. Saini, S. K. S. Kushwaha, Synthesis of some amide derivatives and their biological activity, Int. J. Chem. Tech. Res. 3, 203-209 (2011).

[6] V. Raparti, T. Chitre, K. Bothra, V. Kumar, S. Dangre, C. Khachane, S. Gore, B. Deshmane, Novel 4-(morpholine4-yl)- $N$-(arylidene)benzohydrazides: synthesis, antimycobacterial activity and QSAR investigations, Eur. J. Med. Chem. 44, 3954-3960 (2009). DOI: 10.1016/j.ejmech.2009.04.023 
[7] A. P. G. Nikalje, M. Patel, Y. Ranadeb, R. Deshpande, D. Rajani, Design and synthesis of novel N-substituted morpholino benzamide derivatives as antimicrobial agents, Der Pharmacia Sinica 3, 462-469 (2012).

[8] C. L. Allen, A. R. Chhatwal, J. M. J. Williams, Direct amide formation from unactivated carboxylic acids and amines, Chem. Commun. 48, 666-668 (2012). DOI: $10.1039 / \mathrm{c} 1 \mathrm{cc} 15210 \mathrm{f}$

[9] L. Perreux, A. Loupy, A tentative rationalization of microwave effects in organic synthesis according to the reaction medium, and mechanistic consideratons, Tetrahedron 57, 9199-9223 (2001). DOI: 10.1016/S0040-4020(01)00905-X

[10] L. Perreux, A. Loupy, M. Delmotte, Microwave effects in solvent-free esters aminolysis, Tetrahedron 59, 21852189 (2003). DOI: 10.1016/S0040-4020(03)00151-0

[11] D. O. Jang, D. J. Park, J. Kim, A mild and efficient procedure for the preparation of acid chlorides from carboxylic acids, Tetrahedron Lett. 40, 5323-5326 (1999). DOI: 10.1016/S0040-4039(99)00967-3

[12] S.-Y. Han, Y.-A. Kim, Recent development of peptide coupling reagents in organic synthesis, Tetrahedron $\mathbf{6 0}$, 2447-2467 (2004). DOI: 10.1016/j.tet.2004.01.020

[13] A. Khalafi-Nezhad, A. Parhami, M. N. S. Rad, A. Zarea, Efficient method for the direct preparation of amides from carboxylic acids using tosyl chloride under solvent-free conditions, Tetrahedron Lett. 46, 6879-6882 (2005). DOI: 10.1016/j.tetlet.2005.08.021

[14] C. A. G. N. Montalbetti, V. Falque, Amide bond formation and peptide coupling, Tetrahedron 61, 1082710852 (2005). DOI: 10.1016/j.tet.2005.08.031

[15] D. Mijin, S. Petrović, Microwaves in organic chemistry and organic chemical technology, Hem. Ind. 59, 224 229 (2005). DOI: 537-962:547+663/.665

[16] P. Prieto, A. de la Hoz, A. Diaz-Ortiz, A. M. Rodriguez, Understanding MAOS through computational chemistry, Chemical Society Reviews 46, 431-451 (2017). DOI: $10.1039 / \mathrm{c} 6 \mathrm{cs} 00393 \mathrm{a}$

[17] C. O. Kappe, D. Dallinger, S. S. Murphree, Practical Microwave Synthesis for Organic Chemists: Strategies, Instruments, and Protocols, Wiley- $\mathrm{VCH}$, Weinheim, 2009.

[18] S. Chandrasekhar, M. Takhi, G. Uma, Solvent free $N$ alkyl and $N$-arylimides preparation from anhydrides catalyzed by $\mathrm{TaCl}_{5}$-silica gel, Tetrahedron Lett. 38, 80898092 (1997). DOI: S0040-4039(97)10116-2

[19] R. S. Varma, K. P. Naicker, Solvent-free synthesis of amides from non-enolizable esters and amines using microwave irradiation, Tetrahedron Lett. 40, 6177-6180 (1999). DOI: 10.1016/S0040-4039(99)01209-5

[20] N. S. Cho, H. J. Jeon, D. U. Heo, Microwaveacceleration of carboxamides formation using water soluble condensing agent DMT-MM or DCC, J. Korean Chem. Soc. 56, 658-660 (2012).

DOI : $10.5012 / \mathrm{jkcs} .2012 .56 .5 .658$

[21] C. S. Reddy, A. Nagaraj, P. Jalapathi, Zirconyl chloride promoted highly efficient solid phase synthesis of amide derivatives, Chinese Chem. Lett. 18, 1213-1217 (2007). DOI: 10.1016/j.cclet.2007.08.011
[22] P. Sharma, N. Kaur, P. Sharma, R. Sirohi, D. Kishore, Microwave assisted facile one pot synthesis of novel 5carboxamido substituted analogues of 1,4benzodiazepin-2-one of medicinal interest, Bull. Chem. Soc. Ethiop. 27, 301-307 (2013). DOI: $10.4314 /$ bcse.v27i2.16

[23] C. Ferroud, M. Godart, S. Ung, H. Borderies, A. Guy, Microwave-assisted solvent-free synthesis of $\mathrm{N}$ acetamides by amidation or aminolysis, Tetrahedron Lett. 49, 3004-3008 (2008). DOI: $10.1016 /$ j.tetlet.2008.02.170

[24] L. J. Gooßen, D. M. Ohlmann, P. P. Lange, The thermal amidation of carboxylic acids revisited, Synthesis 1, 160-164 (2009). DOI: 10.1055/s-0028-1083277

[25] L. Perreux, A. Loupy, F. Volatron, Solvent-free preparation of amides from acids and primary amines under microwave irradiaton, Tetrahedron 58, 2155-2162 (2002).

[26] E. Gelens, L. Smeets, L. A. J. M. Sliedregt, B. J. van Steen, C. G. Kruse, R. Leurs, R. V. A. Orru, An atom efficient and solvent-free synthesis of structurally diverse amides using microwaves, Tetrahedron Lett. 46, 37513754 (2005). DOI: 10.1016/j.tetlet.2005.03.146

[27] V. Ćirin-Novta, S. Kevrešan, K. Kuhajda, J. Kandrač, Lj. Radić, P. Rodić, Optimization of petroleum acid isolation from lower oil fractions of Vojvodina "Velebit" oil, Acta Period. Technol. 34, 49-54 (2003). DOI: 10.2298/APT0334049C

[28] L. R. Nascimento, L. M. C. Reboucas, L. Koike, F. de A. M. Reis, A. L. Soldan, J. R. Cerqueira, A. J. Marsaioli, Acidic biomarkers from Albacora oils, Campos basin, Brazil, Org. Geochem. 30, 1175-1191 (1999).

[29] T.-P. Fan, Characterization of naphthenic acids in petroleum by fast atom bombardment mass spectrometry, Energy and Fuels 5, 371-375 (1991). DOI: $10.1021 / \mathrm{ef00027a003}$

[30] J. A. Brient, P. J. Wessner, M. N. Doyle, Kirk-Othmer Encyclopedia of Chemical Technology, John Wiley \& Sons, New York, 1995.

[31] V. Ćirin-Novta, K. Kuhajda, S. Kevrešan, J. Kandrač, Lj. Radić, Biolgical activity and structure of natural petroleum acids from lower oil fractions of "Velebit" oil, Acta Period. Technol. 33, 135-141 (2002). DOI: $10.2298 / \mathrm{APT} 0233135 \mathrm{C}$

[32] V. Ćirin-Novta, S. Kevrešan, K. Kuhajda, J. Kandrač, Lj. Radić, P. Rodić, Structural and physiological properties of natural petroleum acids from middle oil fractions of "Kelebija" oil, Acta Period. Technol. 35, 87-93 (2004). DOI: $10.2298 / \mathrm{APT} 0435087 \mathrm{C}$

[33] Lj. Grbović, K. Pavlović, B. Prekodravac, K. Kuhajda, S. Kevrešan, M. Popsavin, J. Milić, V. Ćirin-Novta, Fractionation of complex mixtures of naphthenic acids, their characterization and biological activity, J. Serb. Chem. Soc. 77, 147-157 (2012). DOI: $10.2298 / J S C 110616195 G$

[34] S. Kevrešan, B. Kovačević, V. Ćirin-Novta, K. Kuhajda, J. Kandrač, K. Pavlović, Lj. Grbović, Biochemical changes in cuttings of Robinia pseudoacacia after treatment with naphthenate, J. Serb. Chem. Soc. 72, 953-959 (2007). DOI: $10.2298 / J S C 0710953 \mathrm{~K}$ 
[35] S. Kevrešan, V. Ćirin-Novta, D. Vasić, K. Kuhajda, J. Kandrač, N. Petrović, Lj. Radić, Effect of naphthenic acids on formation of adventitious roots in sunflower cuttings, Helia 26, 75-82 (2003).

DOI: $10.2298 / \mathrm{HEL} 0339075 \mathrm{~K}$

[36] S. Kevrešan, V. Ćirin-Novta, B. Kovačević, K. Kuhajda, J. Kandrač, N. Petrović, Lj. Radić, Efekat naftenskih kiselina na formiranje korenčića odrvenjenih reznica klonova sekcija leuse i aigeiros, Topola 171, 63-72 (2003).

[37] V. C. Eze, B. N. Eze, Isolation and characterization of microorganisms involved in the degradation of refined petroleum products polluted sites in Elele, Rivers State, Nigeria, Int. J. Curr. Res. 8, 91-95 (2010).

[38] M. Ebrahimi, M. R. Sarikhani, R. Fallah, Assessment of biodegradation efficiency of some isolated bacteria from oil-contaminated sites in solid and liquid media containing oil-compounds, Int. Res. J. Appl. Basic Sci. 3, 138147 (2012)

[39] O. V. Biryukova, P. M. Fedorak, S. A. Quideau, Biodegradation of naphthenic acids by rhizosphere microorganisms, Chemosphere 67, 2058-2064 (2007). DOI: 10.1016/j.chemosphere.2006.11.063
[40] L. F. Del Rio, A. K. M. Hadwin, L. J. Pinto, M. D. MacKinnon, M. M. Moore, Degradation of naphthenic acids by sediment micro-organisms, J. Appl. Microbiol. 101, 1049-1061 (2006).

DOI:10.1111/j.1365-2672.2006.03005.x

[41] E. O. King, M. K. Ward, D. E. Randey, Two simple media for the demonstration of pyocyanin and fluorescin, J. Lab. Clin. Med. 44, 301-307 (1954).

[42] S. Sutton, Measurement of microbial cells by optical density, J. Vaud. Tech. 17, 46-49 (2011).

[43] A. Khalafi-Nezhad, B. Mokhtari, M. N. S. Rad, Direct preparation of primary amides from carboxylic acids and urea using imidazole under microwave irradiation, Tetrahedron Lett. 44, 7325-7328 (2003). DOI: $10.1016 / \mathrm{S} 0040-4039(03) 01866-5$

[44] R. J. Johnson, B. E. Smith, S. J. Rowland, C. Whitby, Biodegradation of alkyl branched aromatic alkanoic naphthenic acids by Pseudomonas putida KT2440, Int . Biodeterior. Biodegrad. 81, 3-8 (2013). DOI: $10.1016 /$ j.ibiod.2011.11.008

[45] J. S. Clemente, P. M. Fedorak, A review of the occurrence, analyses, toxicity, and biodegradation of naphthenic acids, Chemosphere 60, 585-600 (2005). DOI: $10.1016 /$ j.chemosphere.2005.02.065 